\title{
Rotation Invariant Image Matching by Geometrical Parameter of Equidistantly Edge Pixels Group
}

\author{
Hiroki Hayashi Non-member (Gifu University) \\ Fumihiko Saitoh Member (Gifu University)
}

Keyword : Template matching, Edge directions, difference of directions, accumulation processing

The template matching is a method to search a target image area that is similar to a template image in an objective image. The template matching is a simple method. However, the target image must have the right position as the template image. Therefore it needs large computational cost because two-dimensional pose parameters must be set for the sequential matching when the target image has a free location and a free inclination. The paper proposes a method to search a target image area that has a free location and a free inclination by using geometrical parameter of equidistantly edge pixels group.

In this method, the difference of directions is calculated from the edge direction of a referenced edge pixel in an image area and the direction from the referenced edge pixel to other selected edge pixels. The difference of direction is not changed by inclination of an image as shown in Fig.1. The difference of directions of template image and the difference of directions of objective image are matched at each edge pixel. The matched ratio is accumulated



(a) Before rotation

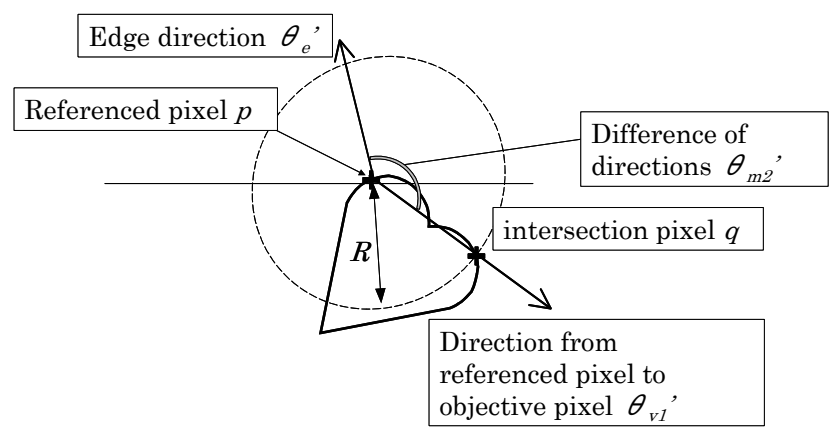

(b) After rotation

Fig. 1. The rotation invariant parameters to the accumulation space. The matched ratio is also accumulated into the inclination histogram that represents the distribution of inclined angles as shown in Fig. 2. Then the location of the target image area is searched by scanning the accumulation space. After that, the inclination histogram is also searched. The maximum peak in the histogram is extracted as the inclination of the target image area.

An example of a template image and a resultant image are shown in Fig. 3. The experimental results show that the processing time of the proposed method is short. The proposed method had higher reliability for matching.

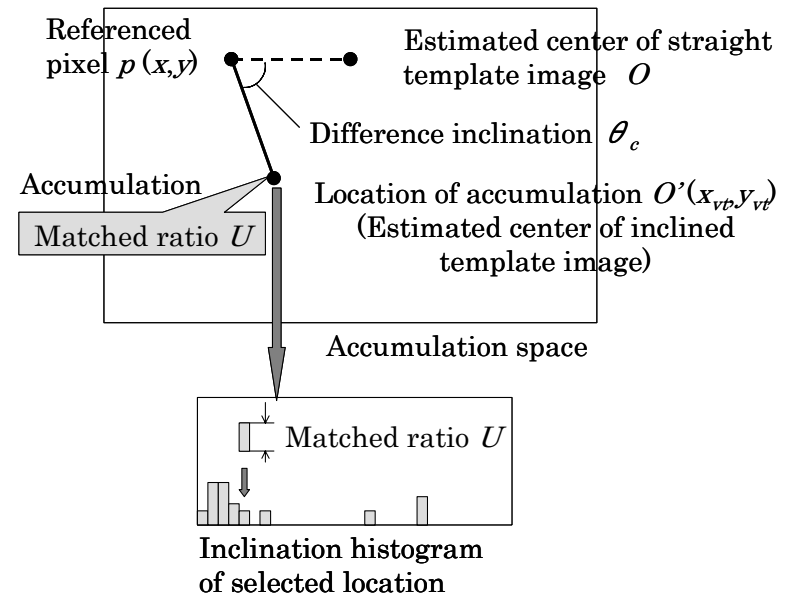

Fig. 2. Accumulation to accumulation space and inclination histogram

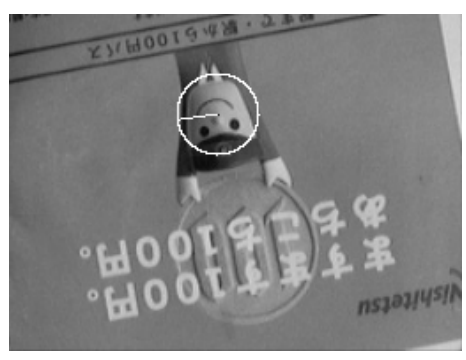

(a) template

(b) image 


\title{
論 文 \\ 等距離エッジ点群の幾何特徵に基づく回転対応画像照合
}

\author{
非会員 林 宏樹* 正員 斉藤 文彦*

\section{Rotation Invariant Image Matching by Geometrical Parameter of Equidistantly Edge Pixels Group}

Hiroki Hayashi*, Non-member, Fumihiko Saitoh*, Member

The template matching is a method to search a target image area that is similar to a template image. However, the target image area must have the right position as the template image generally. Therefore it requires large computational cost when a location and an inclination of the target image area are unknown. This paper proposes a method to search a target image area that has a free location and a free inclination by geometrical parameters obtained by equidistantly edge group. In this method, the difference of directions is calculated by the edge direction of a referenced edge pixel and by the directions from the referenced edge pixel to other selected edge pixels. After that, the matching process is performed by using the difference of directions and matching rates are accumulated. Then the location and inclination of the target image area are searched by scanning the accumulation space. The experimental results show that the proposed method had higher reliability and less computational cost for image matching.

キーワード : テンプレートマッチング, エッジ方向, 方向差, 累積処理

Keywords : Template matching, Edge directions, difference of directions, accumulation processing

\section{1. はじめに}

あらかじめ用意しておいたテンプレート画像と類似した 部分画像を対象の画像内から探索するテンプレートマッチ ングは，テンプレート画像の設定という単純な操作で目的 を達成することができるため, 汎用性が高いことが特長で ある(1)。そのため, 現在では, 計測や位置決め, 久陷検出な どの工業用画像処理を代表とした幅広い分野で使用されて いる。正規化された濃度相関(4)(5)や絶対濃度差の二乗和 ${ }^{(2)(3)}$ に基づく手法は代表的な手法として知られているが，これ らの手法は，画素単位で照合を行うため，探索す心゙き部分 画像は, テンプレート画像に対して正立に近い状態である ことが条件となり, 対象とする画像が任意の傾斜角を持つ 場合には，適用が困難となる。

本論文では, 探索対象となる部分画像が任意な傾斜角を 持つ場合であっても，高速に照合を行う手法を提案する。 画像の 2 次元的な姿勢変化と位置の変化に対して影響を受 けない特徵量として, エッジ画素の相対的な位置関係に着 目する。具体的には, 画像領域内に存在するあるエッジ画

\footnotetext{
* 岐阜大学

可501-1193 岐阜県岐阜市柳戸 1-1

Gifu University,

1-1 Yanagido, Gifu, Gifu 501-1193
}

素と，一定の距離離れた位置に存在しているエッジ画素に ついて, エッジ方向と, 双方のエッジ画素を結ぶ方向との 差を求め, その方向差を照合する。累積した照合結果から, 探索すべき部分画像の位置と傾きを求める。

\section{2. 従来の回転対応画像照合手法}

対象物の 2 次元的な姿勢変化の影響を受けない画像照合 を行う代表的な手法として，一般化 Hough 変換(6) ヒストグ ラム照合法(7)(8)などが提案されている。一般化 Hough 変換 は，エッジ画素を用いて投票処理を行うことにより，姿勢 やスケール変化の影響を受けにくい照合が可能であるが, 各種の姿勢変化に対応しようとすると, 膨大なメモリ空間 と処理時間を要する。

部分画像の濃度ヒストグラムの一致度に基づいて照合を 行うヒストグラム照合法は, 濃度ヒストグラムが回転不変 の特徵量であるため, 画像の 2 次元的な姿勢変化の影響を 受けない照合が可能である。しかし，濃度ヒストグラムに は, 対象物の形状情報が含まれていないため, 探索すべき 部分画像の傾きを直接的に検出することは困難である。ま た, 類似した濃度分布を持つ部分画像において誤照合を起 こす危険性が生じる。画像の方向性を利用した手法として は，エッジ方向のヒストグラムを照合に使用する手法が考 えられる。また著者らも, 形状情報を含んだヒストグラム 


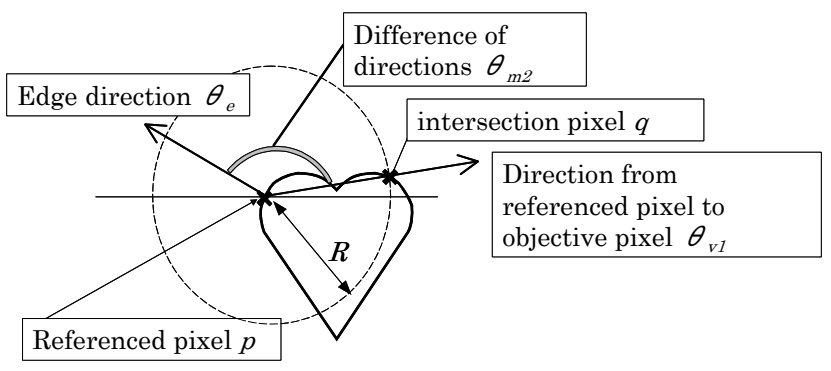

(a) Before rotation

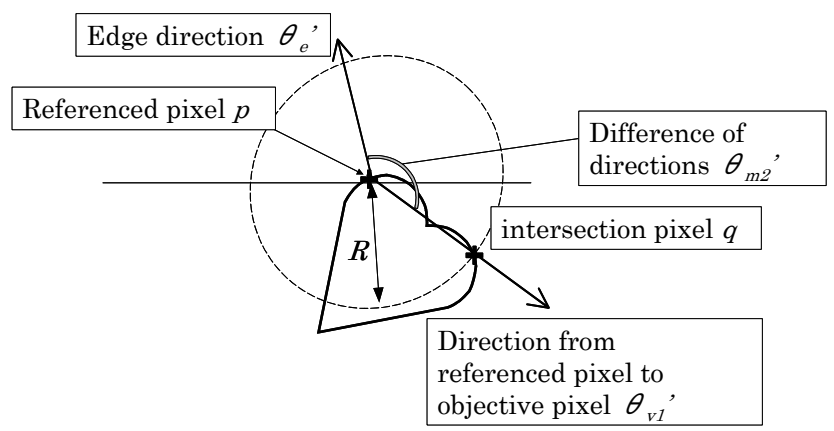

(b) After rotation

図 1 回転不変な特徵量

Fig. 1. Rotation invariant parameters.

として，エッジ方向に基づいた回転不変な特徵量を使用す る画像照合法として幾何エッジヒストグラムを用いた手法 (13)を提案した。これは，2 つの回転不変な特徵量をからな る二次元ヒストグラムの形状の類似性を照合キーとして, 目的とする画像の位置を探索する手法である。しかし，こ れらの手法では，位置と傾き角度を同時に探索するために は，傾きを表すパラメータを新たに適用する，回転角度を 変更しながら複数回の照合を行うなどの処理を追加する必 要があり, 計算コストを要するという問題がある。一方, 本論文で提案する手法は, 複数のエッジ画素間の相対的な 位置関係から計算される幾何学的特徵量を照合キーとして いる点において，文献（13）とは異なるアルゴリズムを採 用している。これによって，位置の探索と同時に回転角度 の検出も可能としている点に特長がある。

\section{3. 等距離エッジ点群の幾何特徵}

提案手法では，以下に示す回転不変な特徵量である方向 差 $\theta$ を使用して照合を行う。図 1(a)に示すように, 画像領 域内のエッジ画素 $p$ を中心とした, 半径 $R$ の円上を走査し, 円と交差するエッジ画素を探索する。画素 $p$ と, 円との交 点となったエッジ画素 $q$ の相対的な位置関係は, 画像の回 転の影響を受けない。例えば，図 1(a)中の画素 $p$ における エッジ方向 $\theta_{e}$ と画素 $p$ から画素 $q$ への方向角 $\theta_{v 1}$ はそれぞ れ，回転した図 1(b)においては， $\theta_{e}, \theta_{v 1}{ }^{\prime}$ 人と変化する。 しかし, $\theta_{e}$ と $\theta_{v 1}$ との差 $\theta_{m 2}$ と, $\theta_{e}$ 'と $\theta_{v 1}$ 'との差 $\theta_{m 2}$ 'は それぞれ等しく, 姿勢変化前と後で変化しない。以下，こ こで説明した $\theta_{m 2}$ のように，あるエッジ画素におけるエッ

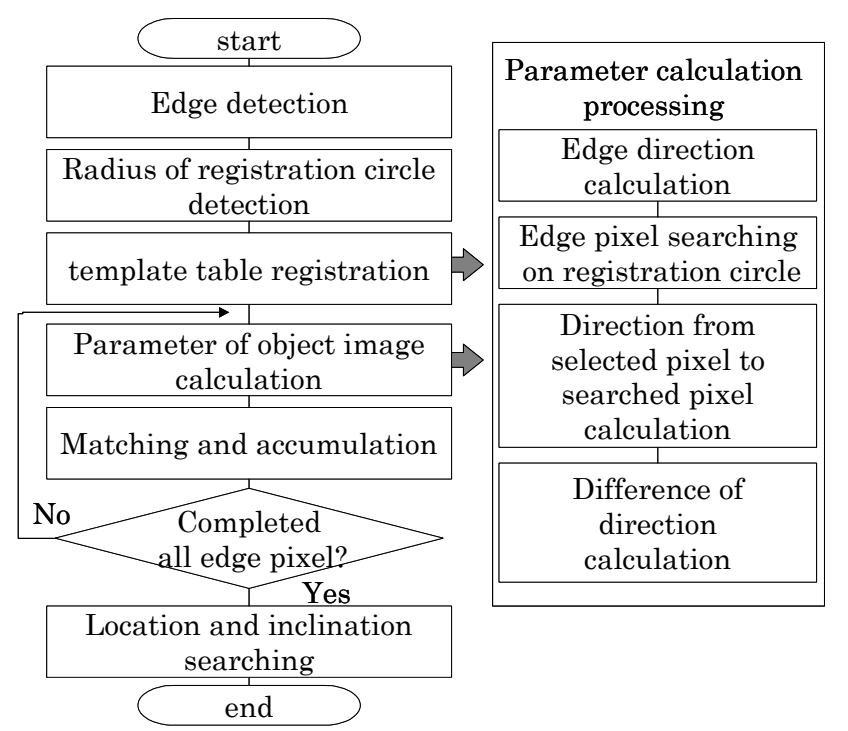

図 2 提案手法の流れ

Fig. 2. Flow-chart of the proposed method.

ジ方向と, そのエッジ画素を中心とする半径 $R$ の円上に位 置するエッジ画素への方向角との差を方向差 $\theta$ と呼ぶこと にする。方向差 $\theta$ は, 画像の回転および位置の変化に対し て不変な特徵量となる。提案手法では, 方向差 $\theta$ を特徵量 とし, 複数の方向差の一致度に基づいて画像照合を行う。 また, 画素 $p$ におけるエッジ方向 $\theta e$ は画像の回転量に等し い変化をおこす。すなわち, 姿勢変化前と後のエッジ方向 $\theta_{e}$ と $\theta_{e}$ ’ の差を求めることで, 画像の傾き角度を求めるこ とが可能となる。そのため, 一回の照合で位置と角度の検 出を行える。

図 2 に手法の流れを示す。円形テンプレート画像からエ ッジ画素を抽出し, テンプレートテーブル登録に必要な半 径 $R$ を決定する。テンプレート登録半径 $R$ に基づいてエッ ジテンプレート画像を走査し, 各エッジ画素について特徴 量を求めてテンプレートテーブルに登録を行う。その後対 象画像の各エッジ画素に対してテンプレートテーブル内の 全てのデータを照合させ, 累積空間と角度候補ヒストグラ ムに累積を行う。全てのエッジ画素に対して累積を行った 後, 累積空間と角度候補ヒストグラムを走査し, 累積值が 最大となる探索すべき部分画像の位置と傾きを求める。以 下に各処理過程について詳しく説明する。

\section{4. テンプレート登録過程}

〈4·1〉 エッジ抽出画像パタンの幾何学的な特徵 は, 主に輪郭をあらわすエッジ部分に現れることから, 提 案手法では, 各エッジ画素における幾何学的特徵量をテン プレートテーブルヘ登録する。エッジ画素は, Sobel オペレ 一タ(9)(10)によってエッジ強度画像を生成し, 判別分析法(11) によって求めた閾值によって 2 值化を行い, 非極大值の抑 制化(12)によって細線化を行うことで抽出する。

〈4·2〉 テンプレート登録半径 〈4・1〉節で得られた エッジ画素について，テンプレートテーブルヘ登録を行う。 


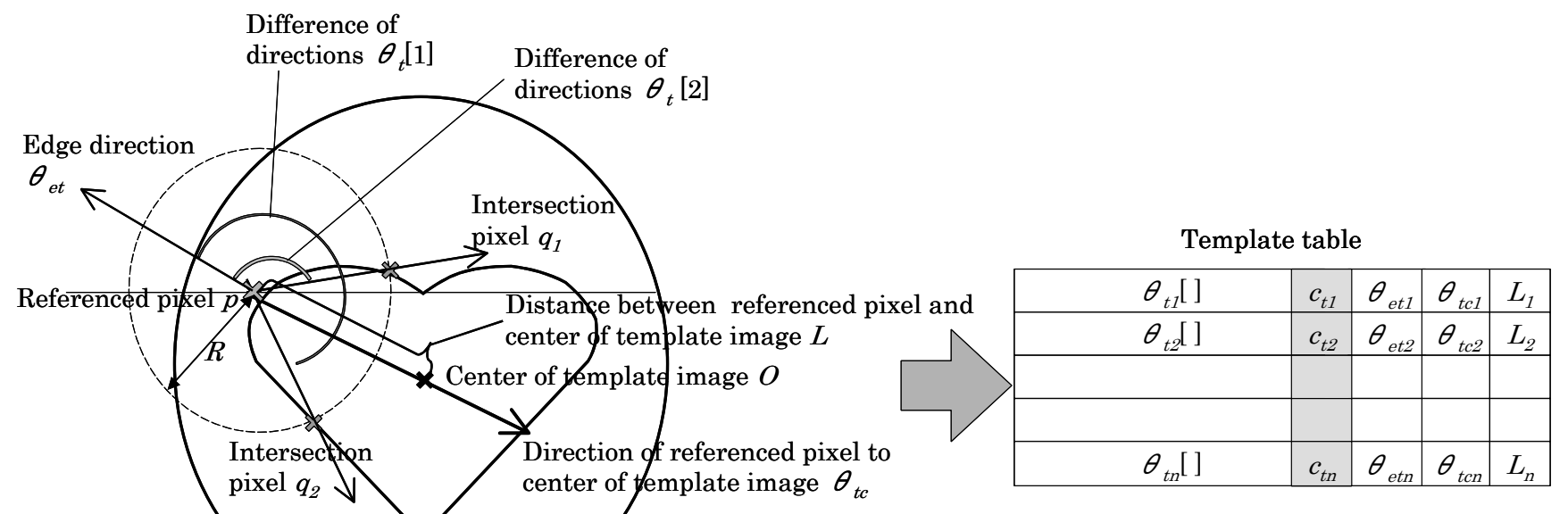

$\mathrm{n}$ : Number of edge pixel in template image

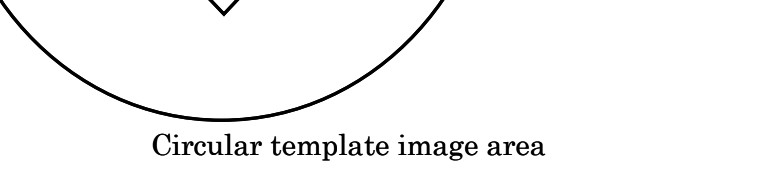

図 3 テンプレートテーブル登録パラメータ

Fig. 3. Parameters of template table registration.

各エッジ画素ごとに，その画素を中心とする半径 $R$ の円と 交差するエッジ画素を, 特徵量の計算の対象とする。この 半径 $R$ をテンプレート登録半径と呼ぶことにする。テンプ レート登録半径 $R$ は, 任意に決定することが可能であるが, テンプレート登録半径 $R$ によって交点画素数が変化し、テ ンプレートテーブルに登録されるデータの数が変動する。 テンプレートによっては, 登録半径 $R$ の值が認識率に大き な影響を与える可能性がある。そこで本手法では，テンプ レート画像中の全エッジ画素から求められる交点画素の総 数が最大となる值とする。これは，照合に使用されるデー タが多い方が照合の信頼性が高くなると考えられるためで ある。各画像について適切なテンプレート登録半径を, 6 章 で述べる実験によって検討を行う。テンプレート登録半径 $R$ は，以下に述べるテンプレートテーブルとは別に記録して おく。

〈4·3〉 テンプレートテーブルの登録テンプレート テーブルへ登録されるパラメータは，図 3 に示すように, 参照エッジ画素 $p$ を中心としたテンプレート登録半径 $R$ の 円と交差するエッジ画素数, 寸なわち交点画素数 $c_{t}$, 参照エ ッジ画素 $p$ のエッジ方向 $\theta e t$, 参照エッジ画素 $p$ からテンプ レート画像中心 $O \sim の$ 方向 $\theta_{t c}$, 参照エッジ画素 $p$ からテン プレート画像中心 $O$ までの距離 $L$, 方向差リスト $\theta_{t}[i](1 \leqq$ $\left.i \leqq c_{t}\right)$ の 5 種類である。これらパラメータは, テンプレート 画像中のエッジ画素数 $n$ だけ登録される。なお，方向差リ スト $\theta_{t}[i]$ とは, 参照エッジ画素 $p$ と, 各交点画素から求め られる方向差 $\theta_{t}$ によって生成されたリストである。参照エ ッジ画素からテンプレート中心までの距離 $L$ と方向 $\theta_{t c}$ は 位置候補の計算に，方向差リスト $\theta_{t}[i]$ は照合に，交点画素 数 $c_{t}$ は一致率の計算に使用する。参照エッジ画素のエッジ 方向 $\theta$ et は, 位置候補の計算と, 画像の傾き角度の推定に使
用される。なお，テンプレートテーブルへ登録されるパラ メータは，エッジ画素毎に計算されるため，対象とする図 形は連結している必要はない。

\section{5. 照合過程}

〈5·1〉方向差リストの照合テンプレートテーブル 登録の後, 登録された方向差のリスト $\theta_{t}\left[{ }_{i}\right]$ との照合を行う。 まず，対象画像中のあるエッジ画素 $r(x, y)$ に対して，テン プレート登録半径 $R$ を用いて交点画素を探索する。交点画 素が存在する場合, 各交点画素に対して, 方向差 $\theta$ を求め, 照合用の方向差のリスト $\theta_{j}$ を生成する。

探索対象画像中の部分画像から生成された, 照合用の方 向差のリスト $\theta_{j}$ と, テンプレートテーブル中の全ての登録

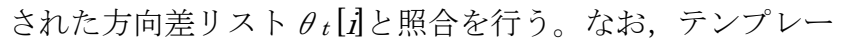
トテーブルに登録された各方向差リストと照合を行う際, 対象画像の回転による量子化誤差や，ノイズの混入によっ て，正しい位置から生成された方向差のリストであっても， 一般的に，完全には一致しない。このような問題を回避す るため, 図 4(a)に示すように, 照合前に, 照合用の方向差

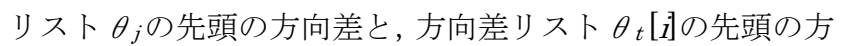
向差との差が最小となる位置を探索し, 図 4(b)のようにシ フトさせる。このとき求めた差が士 $5^{\circ}$ 以上のときは, 信頼 性の低いデータである可能性が高いと考えられるので, 照 合を行わないこととする。

照合は, 図 4(b)に示すようにシフトさせた照合用の方向 差リスト $\theta_{j}$ と, 登録された方向差リスト $\theta_{t}\left[{ }_{i}\right]$ の先頭から行 われる。リスト中の方向差を比較して, 誤差が士5。内内の 場合, 方向差が一致したとみなして, 一致数 $N_{u}$ を 1 増やす。 方向差が一致しない場合, 例えば図 4(c)に示すように, $\theta_{j}[3]$ と $\theta_{t}$ [2]との差が大きく, 一致しないとみなされた場合に 


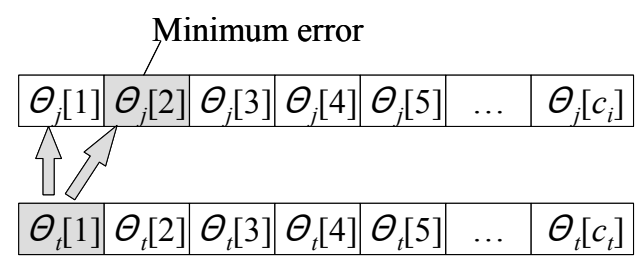

(a) Minimum error searching

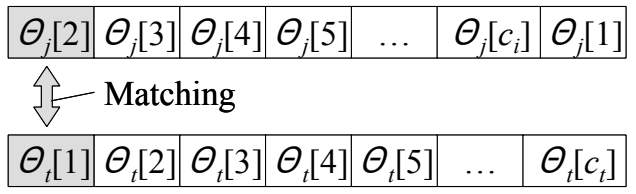

(b) Difference of directions matching (1)

$\mathrm{S}$

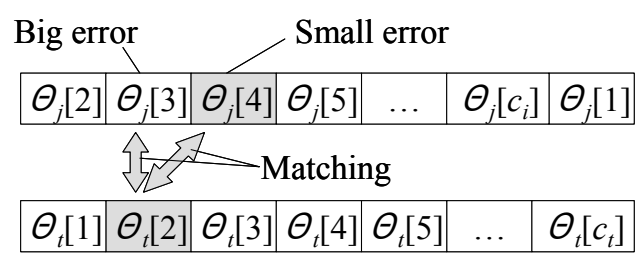

(c) Unmatched difference of directions

\begin{tabular}{|c|c|}
\hline 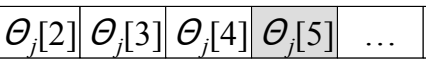 & \begin{tabular}{|l|l|}
$\Theta_{j}\left[c_{i}\right]$ & $\Theta_{j}[1]$ \\
\end{tabular} \\
\hline \multicolumn{2}{|l|}{$\Omega_{\text {Matching }}$} \\
\hline 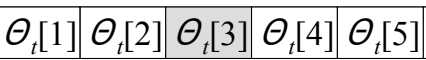 & $\Theta_{t}\left[c_{t}\right]$ \\
\hline
\end{tabular}

(d) Difference of directions matching (2)

図 4 方向差リストの照合

Fig. 4. Matching processing between difference of direction lists.

は，方向差リスト $\theta_{j}$ を走査し， $\theta_{j}[4]$ と $\theta_{t}[2]$ を照合する。 その後, 図 $4(\mathrm{~d})$ に示すように, それぞれの方向差リストで 一致したとみなされた位置の, 次の位置から照合を続ける。 方向差リスト $\theta_{t}$ の最後尾に存在する方向差 $\theta_{t}\left[c_{t}\right]$ の照合が 終了した時点で, 照合によって得られた一致数 $N_{u}$ と交点画 素数 $c_{t}$ から, 下式によって一致率 $U$ を求め, 以下に述べる 累積処理を行う。

$$
U=N_{u} / c_{t}
$$

〈5·2〉位置候補の決定と累積次に，探索す心゙き部 分画像の位置候補 $O^{\prime}\left(x_{V t}, y_{V t}\right)$ を求める。位置候補を求める ための基準点 $O$ は，テンプレート画像領域の中心とした。 位置候補を計算するため, まず，画像の傾きを傾き候補と して求める。傾き候補 $\theta c$ は, 照合を行ったテンプレートテ ーブルに記録された参照画素のエッジ方向 $\theta$ et と対象画像 中の参照画素のエッジ方向 $\theta_{e i}$ から, 下式によって求める。

$$
\theta_{c}=\theta_{e i}-\theta_{e t}
$$

傾き候補と，テンプレートテーブルに登録されているテン プレート中心への方向を加算することで，参照画素からの 相対的な位置候補の方向 $\theta_{v t}$ を求め, テンプレートテーブル に登録された, テンプレート中心までの距離 $L$ を使用し, 下式のように，参照画素を回転の中心として基準点を回転

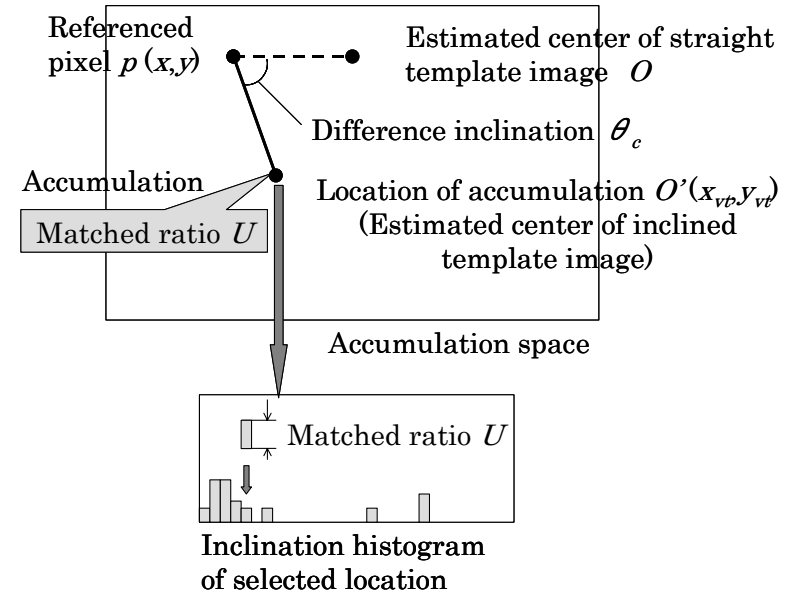

図 5 累積空間と傾き候補ヒストグラムへの累積

Fig. 5. Accumulation into accumulation space and inclination histogram.

させ，位置候補 $O^{\prime}\left(x_{v t}, y_{v t}\right)$ を求める。

$$
\left.\begin{array}{l}
x_{v t}=x+L \cdot \cos \left(\theta_{v t}\right) \\
y_{v t}=y+L \cdot \sin \left(\theta_{v t}\right)
\end{array}\right\}
$$

基準点の回転先が，探索すべき部分画像の候補位置となる。

次に, 画像と同サイズの, 全ての座標を 0 で初期化した 2 次元の累積空間と, 累積空間の各座標に対応した 1 次元の 傾き候補ヒストグラムを準備する。この累積空間内の位置 候補に対応する座標に, 図 5 に示すように, 〈5・1〉節で求 めた一致率 $U$ を重みとした累積を行う。その後, その位置 に対応した傾き候補ヒストグラムに対して, 同様に, 一致 度 Uを重みとして累積する。

$\langle 5 \cdot 3\rangle$ 位置と角度の決定対象画像内に存在する全 てのエッジ画素に対して，〈5・2〉節までの処理を行った後， 累積空間を走査して, 累積值が最大となる座標を探索すべ き部分画像の位置として求める。但し，〈5·2〉 節で求めた 累積位置は実際には実数であり, 累積空間の座標は整数で あるため, 累積処理が, 周囲へ分散する危険性があると考 えられる。このような位置ずれの影響を低減するため, 累 積空間の平滑化を行い, 最大累積值を持つ座標を求める。

最大累積值を持つ座標, すなわち探索すべき部分画像の 位置を決定した後, 画像の傾き角度を決定する。最も頻度 が高い傾き候補が画像の傾きを表すと考えられるため, 最 大累積值を持つ位置に対応した，傾き候補ヒストグラム内 の最大頻度を取る角度を画像の傾き角度とする。そのため, 検出した回転角度に多義性はない。但し, 完全に点対称形 状の対象物の場合は，傾き候補ヒストグラムに 2 つのピー クが発生し, いずれか最大頻度となる方の角度が選択され ると考えられる。傾き候補ヒストグラムについても, 累積 位置の微小な位置ずれの影響を考慮し, 最大累積值を持つ 座標に対応するヒストグラムだけではなく, その近傍 8 座 標に対応する傾き候補ヒストグラムを累積したヒストグラ ムから傾き角度を探索する。 


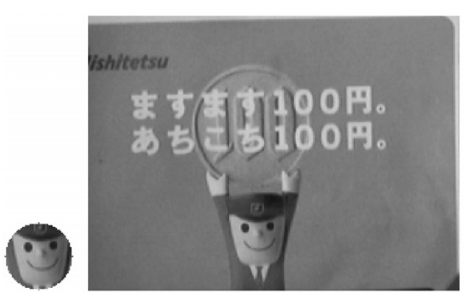

(a) image1

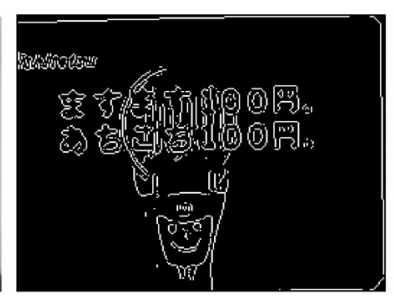

11

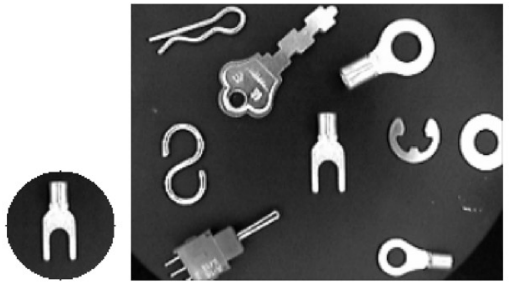

(c) image 3

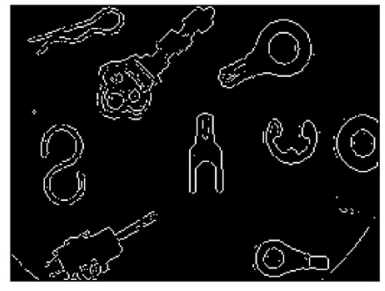

Q

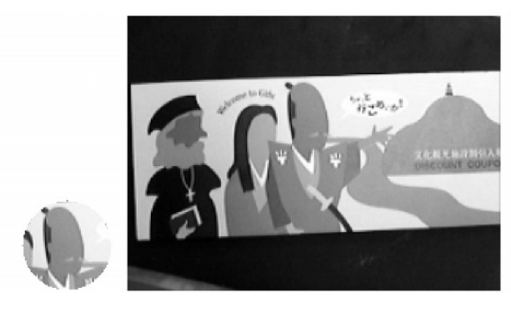

(b) image2

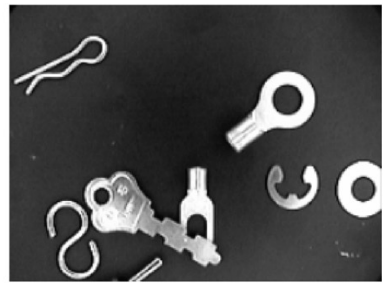

(d) image4
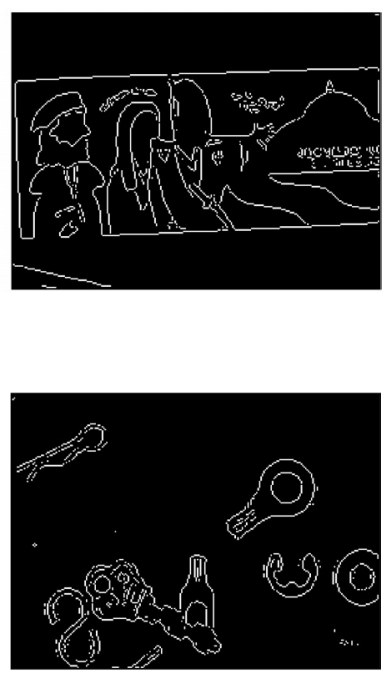

図 6 実験画像例

Fig. 6. Examples of experimental images.

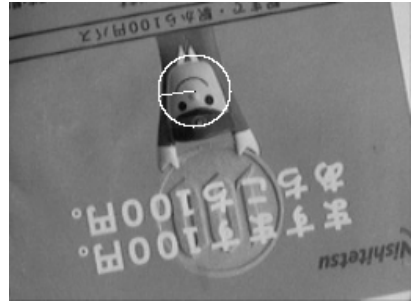

(a) image1 $\left(189^{\circ}\right)$

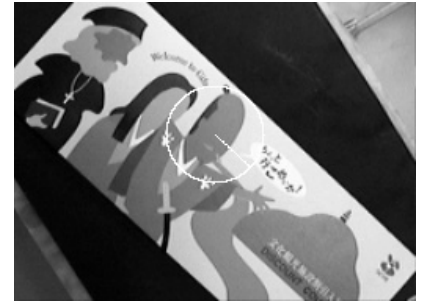

(b) image $2\left(315^{\circ}\right)$

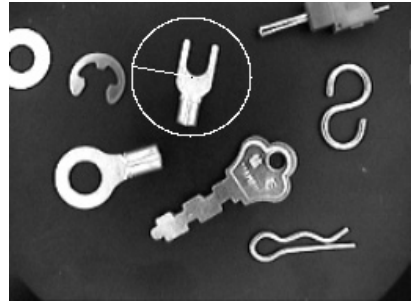

(c) image3 $\left(168^{\circ}\right)$

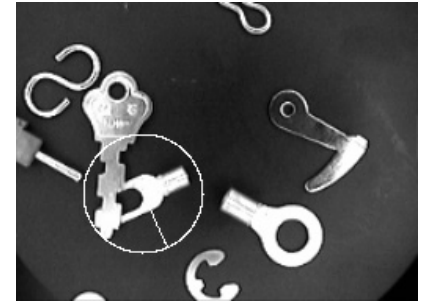

(d) image4 $\left(294^{\circ}\right)$

図 7 探索された画像例

Fig. 7. Examples of searched objective image areas.

\section{6. 実験と結果}

〈6-1〉 実験条件 以上に述べた手法を用い，対象画 像内に存在する, 位置および傾きが不定な部分画像を探索 する実験を行った。図 6 に示す(a)image1，(b)image2, (c)image3, (d)image4の 4 種類の画像を準備し, 機械式夕 ーンテーブルを用い，3 枚の画像を撮影した。対象画像は，すべて 256 階調の濃淡 画像であるが，照合処理の際は，図 6(a), (b), (c), (d)の右 側に示すように, 細線化処理を行ったエッジ画像を用いる。 画像のサイズは $256 \times 192$ 画素である。図 6(a), (b), (c)に ついては, それぞれ, 各画像の左側に示寸, 正立状態の画 像から切り出したテンプレート画像を用意した。図 6(d)の 画像については, 図 6(c)の画像において, 一部に隠蔽が発生 した状態を想定し, 図 6(c) と同一のテンプレート画像を使用 した。テンプレート画像のサイズは，それぞれ，図 6(a)は 直径 47 画素, 図 6(b)は直径 63 画素, 図 6(c) は直径 77 画素 である。処理系には, Pentium4-3.4GHz を用いた。今回は, 比較手法として一般化 Hough 変換, 幾何エッジヒストグラ ム空間を用いる手法を用いた。なお，幾何エッジヒストグ ラム空間を用いる手法のパラメータは, 文献（13）におけ
る実験条件と等しくし，回転角度の検出は行わないことと した。なお, 認識の正誤に関しては, 発見された部分画像 の位置と傾きを目視判定し, \pm 3 画素以内の位置, \pm 5 以 内の傾きであれば探索に成功したと見なした。

〈6·2〉探索結果図 7 に, 探索結果の例を示す。回 転した対象画像から, テンプレート画像と一致性の高い部 分画像が正しく提示されていることがわかる。

表 1 から, image1, image2, image3に関しては, 位置 と角度に関して 100\%の認識率を記録した。一方, image4 に関しては, 98.33\%で, 僅かではあるが誤認識が発生した。 これは, 探索すべき部分画像の一部に隠蔽が発生しており, その部分に関しては照合が正しく行われなかったことが理 由と考えられる。但し，充分に高い認識率が得られている。

表 3 に提案手法との比較のために, 一般化 Hough 変換に よって探索を行った認識率を示す。認識率は, image3 で 2.5\%を示し, image1, image2, image4では 0\%と, 低い 值となった。これは, 実験に使用した画像のエッジ画素が 多く, 部分的に類似した画像パタンが含まれていたことや, 誤投票が非常に多く行われたことが原因と考えられる。ま た, 幾何エッジヒストグラムを用いる手法では, 表 4 で示 すように, image1, image2 では 100\%, image3 では 
表 1 認識率

Table 1. Recognition rates.

\begin{tabular}{c|c|c}
\hline \hline Image & Radius of registration & Recognition rate (\%) \\
\hline image 1 & 20 & 100.00 \\
\hline image 2 & 36 & 100.00 \\
\hline image 3 & 19 & 100.00 \\
\hline image 4 & 19 & 98.33 \\
\hline
\end{tabular}

表 2 処理時間とエッジ画素数

Table 2. Processing time and number of edge pixels.

\begin{tabular}{c|c|c|c}
\hline \hline Image & $\begin{array}{c}\text { Number of } \\
\text { edge pixels } \\
\text { (template) }\end{array}$ & $\begin{array}{c}\text { Number of } \\
\text { edge pixels } \\
\text { (objective image) }\end{array}$ & $\begin{array}{c}\text { Processing } \\
\text { time (sec.) }\end{array}$ \\
\hline image 1 & 236 & 4014 & 2.73 \\
\hline image 2 & 270 & 2318 & 1.54 \\
\hline image 3 & 183 & 1535 & 0.70 \\
\hline image 4 & 183 & 1642 & 0.77 \\
\hline \multicolumn{4}{|r}{}
\end{tabular}

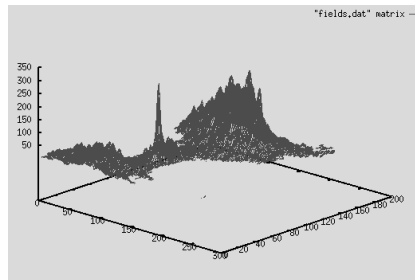

(a) image $1\left(189^{\circ}\right)$

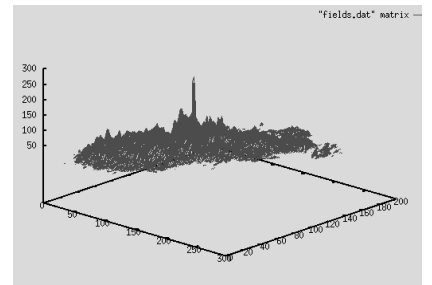

(b) image2 $\left(315^{\circ}\right)$

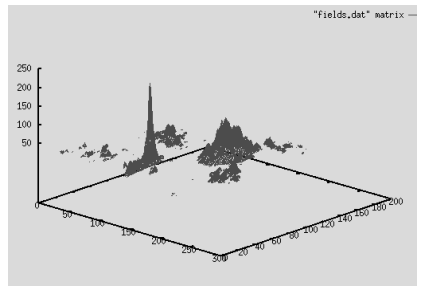

(c) image $3\left(168^{\circ}\right)$

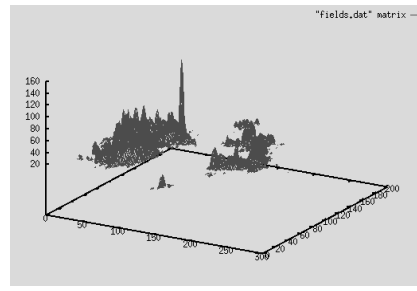

(d) image4 $\left(294^{\circ}\right)$

困 8 累積空間の例

Fig. 8. Examples of accumulation space.

99.16\%, image4 では 73.33\%となり，一般化 Hough 変換 と比較して有効性が確認されたが，提案手法には及ばなか った。これは, 類似した形状の部品の存在や, 隠蔽による ヒストグラムの形状変化が影響したものと考えられる。

図 8 は, 図 7 に示した各結果について, 累積空間内の累 積值の分布状態を示す。いずれの画像についても，正しい 位置で大きな累積值のピークが存在していることがわか る。

〈6-3〉処理時間提案手法による処理時間と各画像 におけるエッジ画素数を表 2 に示す。処理時間は，後述す るテンプレート登録半径の設定処理も含めたテンプレート 登録および結果画像の表示の処理も含めて, 0.7 秒から 3 秒 程度であった。これは，表 3 ，表 4 に示す，一般化 Hough 変換の 3〜4秒程度や, 幾何エッジヒストグラムを用いる手 法での 3 秒から 5 秒程度と比較して十分高速であるといえ る。また, 対象画像に存在するエッジ画素が多いほど処理 時間を要している。処理時間の内訳を調査したところ，方 向差リストの照合に計算コストを費やしていることが分か った。提案手法では, 対象画像中の全てのエッジ画素につ
いて，テンプレートテーブルに登録された全ての方向差リ ストを照合している。この処理の中には, 正しい位置へ累 積されない照合が多数含まれていることから，例えば方向 差リストのデータ数が明らかに異なる場合には照合を行わ ないなどの条件を付加することにより, 処理時間を短縮で きる可能性がある。

〈6・4〉 テンプレート登録半径テンプレート登録半 径が，認識率に与える影響を評価するための実験を行った。 実験を行ったテンプレート登録半径は，提案手法によって 自動的に決定された值, 定数および各テンプレート画像の 半径の 3 種とした。なお, 定数には, 表 1 に示す, 各画像 について提案手法によって自動決定されたテンプレート登 録半径の平均值である 24 を用いた。表 5 は，定数，すなわ ち自動決定された半径の平均值を用いた場合の認識率, 表 6 はテンプレート画像の半径を用いた場合の認識率を示す。 表 1 , 表 5 , 表 6 から, テンプレート登録半径は, 交点画素 の総数が最大となる值に自動決定した場合に認識率が最も 高いことが分かる。特に image1 と image4については，提 案手法によって自動決定された登録半径を使用しない場 
表 5 認識率 (テンプレート登録半径=定数)

Table 5. Recognition rates.

(radius of registration is constant).

\begin{tabular}{c|c|c}
\hline \hline Image & Radius of registration & Recognition rate (\%) \\
\hline image 1 & 24 & 90.00 \\
\hline image 2 & 24 & 100.00 \\
\hline image 3 & 24 & 99.17 \\
\hline image 4 & 24 & 95.83 \\
\hline
\end{tabular}

表 6 認識率 (テンプレート登録半径=テンプレート半径)

Table 6. Recognition rates

(radius of registration is half of template size).

\begin{tabular}{c|c|c}
\hline \hline Image & Radius of registration & Recognition rate (\%) \\
\hline image 1 & 23 & 94.17 \\
\hline image 2 & 31 & 100.00 \\
\hline image 3 & 38 & 100.0 \\
\hline image 4 & 38 & 80.83 \\
\hline
\end{tabular}

合，大きな認識率の低下が見られた。これは，照合に使用 する特徵量の数が増加したためであると考えられる。つま り，常識的に考えて，照合に用いる画素数が少ないよりは 多いほうが信頼性の高い結果が得られるであろうという予 想によるものである。しかし，「交点画素数が最大となる半 径の場合に認識率が最高となる」ことを保証するものでは ない。今回実験を行った, 定数半径, テンプレート画像の 半径, 交点画素数から決定した半径の中では, 交点画素数 が最大となるように自動設定した半径のとき，もっとも良 好な結果が得られたということである。以上の結果より， テンプレート登録半径は, 提案手法で用いた, 交点画素の 総数が最大となる值が適切であると考えられる。

\section{7. まとめ}

エッジ画素のエッジ方向と, 一定距離に存在する他のエ ッジ画素への方向からなる方向差の類似度に基づいて, 2 次 元的な位置および傾きについて姿勢自由度を持つ部分画像 を探索する手法を提案した。実験結果から，提案手法が， 任意に回転した部分画像の位置と傾きを安定して探索でき ることを示した。また，テンプレート登録半径のサイズに ついて評価したところ, 交点画素の総数が最大となるサイ ズに設定した場合に，高い信頼性を得られることがわかっ た。提案手法は, 照合に要する計算コストが低いといえる が，実利用化を考えた場合，特に，エッジ画素が多い場合 には，更なる処理時間の短縮が必要である。

テンプレートテーブル登録時に有効性の高いデータのみ を登録し, 照合回数を削減する処理, 一致率が低い場合に は累積を行わない処理, 照合を行う条件の見直し等によっ て, 更なる探索性能の向上と高速化を達成することが今後 の課題である。

(平成 17 年 4 月 28 日受付, 平成 17 年 12 月 20 日再受付)

\section{文献}

（1）水谷栄二:「グレースケールパターンマッチングを用いた FA 用画像 処理装置とその応用例」, O plus E, Vol.141, pp.141-152 (1991)

(2) D.I.Barnea and H.F.Silverman : "A class of algorithms for fast digital image registration", IEEE Trans. Comput., Vol.C-21, No.2, pp.179-186 (1972)

(3) J.K.Aggarwal, L.S.Davis, and W.N.Martin : "Correspondence process in dynamic scene analysis", Proc. IEEE, Vol.69, No.5, pp.562-572 (1981)

(4) W.M.Silver : "Normalized correlation search in alignment, gauging, and inspection", SPIE, Vol.755, pp23-24 (1987)

(5) J. P. Secilla and N. Garcia : "Template location in noisy pictures", Signal Process., Vol.14, pp347-361 (1988)

(6) D.H.Ballard : "Generalizing The Hough Transform to Detect Arbitrary Shapes", Pattern Recognition, Vol.13, No.2, pp.111-122 (1981)

(7) H. Murase and V.V.Vinod : "Fast Visual Search Using Focussed Color Matching -Active Search-", IEICE Trans., Vol.J81-D- II , No.9, pp.2035-2042 (1998-9) (in Japanese)

村瀬 洋・V.V.Vinod：「局所色情報を用いた高速物体探索一アクテ イブ探索法—」, 信学論 (D- II ) , J-81-D- II , 9, pp.2035-2042 (1998-9)

(8) M.J.Swain and D.H.Ballard : "Color Indexing", IJCV, Vol.7, No.1, pp.11-32 (1991)

(9) I.E.Abdou and W.K.Pratt : "Quantitative Design and Evaluation of Enhancement/Thresholding Edge Detectors", Proc. of the IEEE, Vol.67, No.5, pp.753-763 (1979)

(10) L.Kitchen and A.Rosenfeld : "Edge Evaluation Using Local Edge Coherence", IEEE Trans. on SMC, Vol.11, No.9, pp.597-605 (1981)

(11) N.Otsu : "A Threshold selection Method from Gray-level Histograms", IEEE Trans. SMC, Vol.9, No.1, pp.62-66 (1979)

(12) A.Rosenfeld and M.Thurston : "Edge and Curve Detection for Visual Scene Analysis", IEEE Trans. Comput., Vol.20, No.5, pp.562-569 (1971)

(13) H.Hayashi and F.Saitoh : "Rotation Invariant Image Matching Using Geometrical Edge Histogram Space", IEEJ Trans. EIS, Vol.126-C, No.2, pp.203-209 (2006-2) 林 宏樹・斉藤文彦: 「幾何エッジヒストグラム空間を用いた回転対 応画像照合」, 電学論 C, 126, 2, pp.203-209 (2006-2)

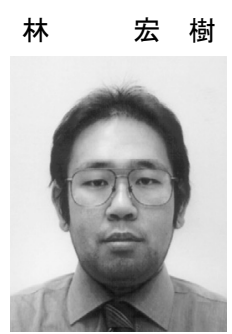

(非会員) 2005 年 3 月岐阜大学大学院工学研 究科応用情報学専攻卒業。同年, 岐阜大学大学 院工学研究科電子情報システム工学専攻入学。 画像照合手法の研究に従事。

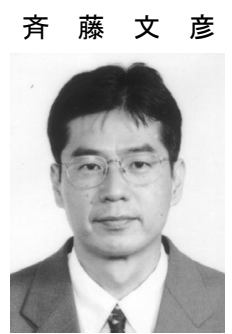

（正員） 1981 年慶大・工・数理卒. 日本 IBM （株）等を経て 1999 年岐阜大学工学部応用情 報学科助教授. 2003 年同教授. マシンビジョン, 視覚情報処理の研究に従事. 博士（情報科学, 工学)。1 1998 年精密工学会優秀論文小田原賞受 賞. 電子情報通信学会, 画像電子学会, 日本視 覚学会, 情報処理学会等会員. 